Gynecol. Invest. 1977;8:133-135

\title{
Contents, Vol. 8, No. 3-4, 1977
}

\section{Symposium on}

Nucleic Acid Metabolism of

Placenta and Fetus

Editor T.T. Hayashi

Pittsburgh, Pa.

10 figures, 10 tables, 1977

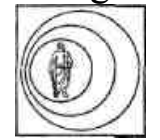

S. Karger $\cdot$ Basel $\cdot$ München $\cdot$ Paris $\cdot$ London $\cdot$ New York $\cdot$ Sydney All rights reserved.

No part of this publication may be translated into other languages, reproduced or utilized in any form or by any means, electronic or mechanical, including photocopying, recording, microcopying, or by any information storage and retrieval system, without permission in writing from the publisher.

(C) Copyright 1977 by S. Karger AG, 4011 Basel (Switzerland), Arnold-Böcklin-Strasse25

Printed in Switzerland by Buch- und Offsetdruckerei Kohlhepp AG, 4123 AUschwil

Contents

Foreword 137

V $\gamma$ jllee, C.A.: Nucleic Acid Structure and Function 139

Villee, C.A.: Synthesis of Proteins in the Placenta 145

Gusseck, D.J.: Role of Nucleic Acids in the Regulation of Human Placental Lactogen Synthesis 162

Hayashi, T.T.: Measurement of Changes in the Constituents of Nucleic Acids (Total DNA and RNA) in the Placenta during the Course of Pregnancy

Wasserman, M.S. and Rosso, P.: Changes in Nucleic Acid Metabolism during Early Embryological and Fetal Growth 195 